\title{
Effects of conspecific adults, macroalgae and height on the shore on recruitment of an intertidal limpet
}

\author{
G. P. Quinn* \\ Department of Zoology, University of Melbourne, Parkville, Victoria 3052, Australia
}

\begin{abstract}
A field experiment was done to examine the effects of cover of macroalgae, density of conspecific adults and height on the shore on the recruitment (up to 2 wk after settlement) of the intertidal limpet Siphonaria diemenensis. In areas where macroalgae were removed recruits numbered significantly less than in areas with natural cover of macroalgae; and at equivalent adult density and macroalgal cover, fewer juveniles recruited to high-shore areas compared to mid-shore areas. There was no effect of adult density, indicating that density-dependent recruitment does not regulate populations of $S$. diemenensis at this site.
\end{abstract}

Patterns of settlement (attachment to substratum and metamorphosis) and recruitment (survival for some time period after settlement; see Keough \& Downes 1982) of benthic marine invertebrates have attracted much recent attention from ecologists. In particular, the importance of spatial and temporal variations in these patterns in structuring rocky intertidal populations and communities has been emphasised by Underwood \& Denley (1984) and others. There have, however, been few field studies which have experimentally examined the factors which affect settlement and/or survival of juvenile intertidal animals, particularly gastropods (see reviews by Underwood 1979, Branch 1981).

This note describes a field experiment which examined the effects of the density of conspecific adults, cover of encrusting macroalgae (Ralfsia spp.) and height on the shore on the recruitment of the intertidal pulmonate limpet Siphonaria diemenensis (Quoy \& Gaimard 1833). Study area was the mid littoral zone of the rocky shore at Griffith Point, Victoria, Australia, where this species spawns benthic egg masses between August and April from which planktotrophic larvae hatch (Quinn 1988a). This shore and the population dynamics of $S$. diemenensis have been

\footnotetext{
- Present address: Department of Zoology, Monash University, Clayton, Victoria 3168, Australia
}

described by Quinn (1988b), and this experiment was done in Zone 1 (Quinn 1988b) on a gently sloping, sandstone substratum. The density of $S$. diemenensis was ca $1000 \mathrm{~m}^{-2}$ (Quinn 1988b). Size-frequency distributions of $S$. diemenensis, collected at ca 2-monthly intervals from 3 permanent study sites (Quinn 1988b) and 10 permanently marked $0.25 \mathrm{~m}^{2}$ quadrats (Quinn 1985), indicated that most recruitment occurred between May and July in 1981. A small number of recruits were present before May, however, and some new recruits continued to arrive until October 1981. A similar pattern had been observed in 1980. The number of new recruits in July 1981 was not correlated with the number of adults on the quadrats (Spearman $\mathrm{r}_{\mathrm{s}}=0.09$, $p>0.05)$ but was correlated with the cover of encrusting macroalgae $\left(\mathrm{r}_{\mathrm{s}}=0.59, p<0.05\right)$.

The experiment ran from 11 May 1981 to 7 July 1981 and was set up in the mid-shore region, 0.4 to $0.5 \mathrm{~m}$ above Chart Datum. Experimental treatments were enclosed within fences $(15 \times 15 \times 2 \mathrm{~cm}$ high $)$ made of woven stainless steel mesh (20 gauge, 3 mesh $\mathrm{cm}^{-1}$ ) and attached to the substratum with stainless steel screws and rawl plugs. An orthogonal design used densities of adults (9.5 to $10.4 \mathrm{~mm}$ shell length) of 5,15 and 30 per enclosure, with 15 representing natural density. Cover of the encrusting macroalgae was left intact ('normal', $<10 \%$ at the start of the experiment, increasing to between 30 and $40 \%$ at the end) or removed with a scraper and a wire brush ('zero').

Effects of height on the shore and 'total' cover of encrusting algae were also examined. These were set up as non-orthogonal treatments because few areas of total algal cover were available in May and resources did not allow the entire experiment to be done at more than one height. These additional treatments were an area of 90 to $100 \%$ cover of Ralfsia spp. ('total') with 15 adults per enclosure and an area of normal algal cover with 15 adults per enclosure set up $0.6 \mathrm{~m}$ above the 
level of the other treatments ('upper-shore'), where the density of Siphonaria diemenensis was ca $400 \mathrm{~m}^{-2}$.

There were 3 replicate enclosures of each treatment arranged randomly on the shore. At 2-weekly intervals (22 May, 8 Jun, 20 Jun, 27 Jul), the number of new recruits within each enclosure was recorded and these were then removed with a fine-pointed knife. Densities of adults and the zero cover of macroalgae were also maintained at these times. Recently settled juvenile Siphonaria diemenensis ( $<0.5 \mathrm{~mm}$ shell length) were difficult to identify to species but, as no other species except $S$. diemenensis were present in the study area, all juveniles were assumed to be this species.

The data were analysed with a 2-factor analysis of variance (Algal cover and Adult density both fixed factors), with the 2 non-orthogonal treatments compared to the other treatments (see Winer 1971), at each date. Planned comparisons compared each non-orthogonal treatment (total algal cover and upper-shore) to the treatment with normal algal cover in the mid-shore (adult density $=15$ in each case) using $t$-tests (standard error and degrees of freedom of these tests were based on the residual mean square and residual degrees of freedom respectively). The significance levels of these tests were adjusted using Sidak's method (Sokal \& Rohlf 1981) because the comparisons were not orthogonal. The data were transformed to natural logarithms, which removed the positive relationship between means and variances and provided homogeneous variances (Cochran's test, $p>0.5$ for each date).

No recruits were recorded in the experimental enclosures on 22 May, and most arrived between then and 8 June (Fig. 1). The analysis of variance (Table 1) showed there was no effect of adult density on the numbers of recruits on any date and no interactions between adult density and algal cover. However, significantly fewer recruits were present in enclosures without macroalgae compared to those with normal cover on each date (Table 1, Fig. 1). There was no
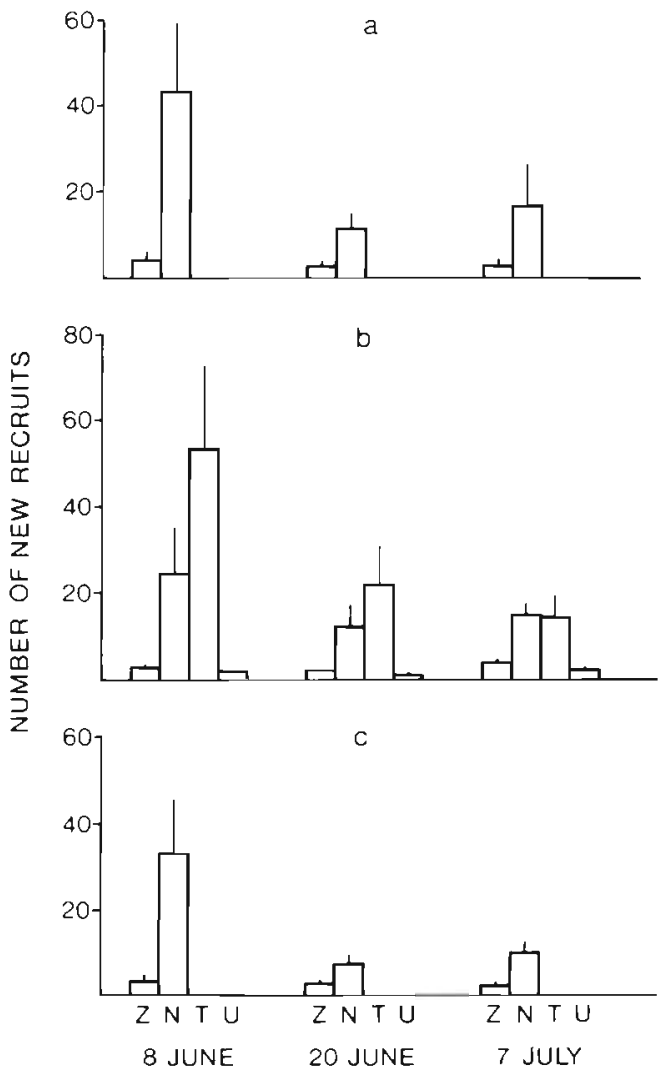

Fig. 1. Siphonaria diemeneisis. Mean $(+\mathrm{SE}, n=3)$ number of new recruits recorded at 2 -weekly intervals. Adult densities per enclosure: (a) $5 ;$ (b) $15_{i}$ (c) $30 . \mathrm{Z}_{i}$ zero algae; $\mathrm{N}$ : normal algae; $T$ : total algae; $U$ : upper-shore

significant difference between normal and total algal cover on any date $\left(8 \mathrm{Jun}: t_{16}=1.40, \mathrm{NS} ; 20 \mathrm{Jun}: t_{16}=\right.$ $1.04, \mathrm{NS} ; 7 \mathrm{Jul}: t_{16}=0.35$, NS), although the mean number of recruits on total algal cover was twice that on normal cover on the first date (Fig. 1). Significantly fewer recruits occurred at the higher level of the shore on all dates ( 8 Jun: $t_{16}=3.59, p<0.01 ; 20$ Jun: $t_{16}=$ 4.56, $p<0.001 ; 7$ Jul: $t_{16}=3.63, p<0.01$ ).

Table 1 Siphonaria diemenensis. Analyses of variance on number of recruits (transformed to natural logarithms) recorded in enclosures on 8 June, 20 June and 7 July

\begin{tabular}{|c|c|c|c|c|c|c|c|}
\hline Source of variation & $\begin{array}{l}\text { Degrees of } \\
\text { freedom }\end{array}$ & $\begin{array}{l}\text { Mean } \\
\text { square }\end{array}$ & Fratio & $\begin{array}{l}\text { Mean } \\
\text { square }\end{array}$ & $F$ ratio & $\begin{array}{l}\text { Mean } \\
\text { square }\end{array}$ & F ratio \\
\hline $\begin{array}{l}\text { Upper shore vs Total } \\
\text { algal cover vs Rest }\end{array}$ & 2 & 6.99 & $13.2 \cdots$ & 5.49 & $15.7 \cdots$ & 2.42 & $5.5^{\circ}$ \\
\hline Algal cover $(A C)$ & 1 & 24.28 & $37.9 \cdots$ & 8.66 & $24.0 \cdots$ & 9.27 & $22.0^{\cdots}$ \\
\hline Adult density (Ad) & 2 & 0.11 & $0.2 \mathrm{NS}$ & 0.09 & $0.2 \mathrm{NS}$ & 0.60 & $1.4 \mathrm{NS}$ \\
\hline Ac $\times$ Ad & 2 & 0.11 & $0.2 \mathrm{NS}$ & 0.33 & $0.9 \mathrm{NS}$ & 0.04 & $0.1 \mathrm{NS}$ \\
\hline Residual & 16 & 0.53 & & 0.35 & & 0.44 & \\
\hline
\end{tabular}


Underwood (1979) listed height on the shore, desiccation, low air temperatures producing frosts, wave action, density of adults and the presence of sessile animals or algae as factors which have been reported to affect the settlement and/or subsequent survival of juvenile gastropods on rocky shores. In this study, desiccation was unlikely to be important as recruitment occurs from the start of winter onwards when air temperatures and the period of daylight exposure to air are declining (Parry 1982, Quinn 1988b). Air temperatures are never low enough at Griffith Point to produce frosts and differences in wave action would not be important on such a small spatial scale as within the present study area. Sessile animals (e.g. mussels or barnacles) were absent in the part of Griffith Point where the experiments were done. Predation can also be important (Underwood et al. 1983, Fairweather 1985), the potential predators on Siphonaria diemenensis being whelks, birds and fish (Parry 1977, 1982). However, whelks were uncommon in this area and birds (oystercatchers) do not feed on S. diemenensis (Parry 1977). Fish (wrasses) do consume $S$. diemenensis, but they were unlikely to be major predators on limpets this small (see Parry 1977, Quinn 1988b).

Positive correlations between the densities of juvenile and adult limpets have been reported by Frank (1965) and Branch (1975). Creese (1981) also demonstrated that for a number of species of limpets in New South Wales, including 2 species of Siphonaria, areas on the shore with large numbers of adults were also areas where recruitment was successful. In this study, however, there was no apparent relationship between the densities of juveniles (recruits) and adults of $S$. diemenensis and this was supported by the experimental data which showed no effect of the density of adults on the recruitment of juveniles. It appears that any density regulation of $S$. diemenensis is not influenced by recruitment processes, at least in the first 2 wk after settlement. Black (1977), Choat (1977) and Creese (1982) have also found that the recruitment of juvenile limpets was not related to the density of adults on a small scale.

Underwood (1976) reported that the juveniles of 2 species of intertidal gastropods in New South Wales showed a preference for habitats containing encrusting algae. The present data also indicate significantly more recruits of Siphonaria diemenensis in areas with encrusting macroalgae. It may be that the occurrence of any amount of macroalgae is the critical cue because total $(100 \%)$ cover of macroalgae did not attract significantly more recruits than normal cover; the difference between the means in the first 2 wk period, however, suggests that the effects of a range of algal covers, rather than just presence and absence, would be worth investigating. Underwood (1980) has also recorded juvenile (up to 1 mo after settlement) Siphonaria diemenensis occurring in fences with macroalgae, and amongst low-shore algae, on a rocky shore in New South Wales, although treatments with different algal covers were not available for comparison.

It is not known whether the greater numbers of recruits of Siphonaria diemenensis in areas with macroalgae were due to preferential settlement or differential survival after settlement. The cover of macroalgae may provide a food supply for settling limpets; adult limpets feed primarily on this encrusting macroalgae (Quinn 1988b), although the diet of these new recruits has not been determined. Fretter \& Manly (1977) have shown that the larvae of 2 species of intertidal gastropods in England metamorphosed on algae on which older individuals occurred and consumed. Alternatively, the algae may simply provide a heterogeneous substratum with more microhabitats or greater surface area for settling limpets. Similar explanations for the effects of algae (Lewis \& Bowman 1975) and barnacles (Hawkins \& Hartnoll 1982) on the recruitment of Patella vulgata have been proposed. Quinn (1988b) has shown the importance of macroalgae for the survival of adult $S$. diemenensis, and there may be some advantages for juveniles showing a preference for this substratum.

This study demonstrates that the importance of various factors affecting the recruitment processes of an intertidal gastropod can be examined experimentally in the field. The paucity of similar studies may be due to the fact that there are few suitable species, such as Siphonaria diemenensis, which recruit in high densities over a short and predictable period. Until more information of this type becomes available, however, a large gap remains in our understanding of the ecology of intertidal gastropods.

Acknowledgements. I thank Drs R. W. Day, P. G. Fairweather, M. J. Littlejohn, K. A. McGuiness, G. D. Parry, R. N. Synnot and A. J. Underwood for helpful comments on this work and/ or the manuscript. Support came from the Department of Zoology, University of Melbourne and the School of Biological Sciences, University of Sydney

\section{LITERATURE CITED}

Black, R. (1977). Population regulation in the intertidal limpet Patelloida alticostata (Angas, 1865). Oecologia (Berl.) 30: 9-22

Branch, G. M. (1975). Intraspecific competition in Patella cochlear Born. J. Anim. Ecol. 44: 263-282

Branch, G. M. (1981). The biology of limpets: physical factors, energy flow and ecological interactions. Oceanogr. mar. Biol. A. Rev. 19: 235-379

Choat, J. H. (1977). The influence of sessile organisms on the population biology of three species of acmaeid limpets. $\mathrm{J}$. exp. mar Biol. Ecol. 26: 1-26 
Creese, R. G. (1981). Patterns of growth, longevity and recruitment of intertidal limpets in New South Wales. J. exp. mar. Biol. Ecol. 51: 145-171

Creese, R. G. (1982). Distribution and abundance of the acmaeid limpet, Patelloida latistrigata, and its interaction with barnacles. Oecologia (Berl.) 52: 85-96

Fairweather, P. G. (1985). Differential predation on alternative prey, and the survival of rocky intertidal organisms in New South Wales. J. exp. mar. Biol. Ecol. 89: 135-156

Frank, P. W (1965). The biodemography of an intertidal snail population. Ecology 46: 831-844

Fretter, V., Manly, R. (1977). Algal associations of Tricolia pullus, Lacuna vincta and Cerithiopsis tubercularis (Gastropoda) with special reference to the settlement of their larvae. J. mar. biol. Ass. U.K. 57: 999-1017

Hawkins, S. J., Hartnoll, R. G. (1982). The influence of barnacle cover on the numbers, growth and behaviour of Patella vulgata on a vertical pier. J. mar. biol. Ass. U.K. 62: 855-867

Keough, M. J., Downes, B. J. (1982). Recruitment of marine invertebrates: the role of active larval choices and early mortality. Oecologia 54: 348-352

Lewis, J. R., Bowman, R. S. (1975). Local habitat-induced variations in the population dynamics of Patella vulgata L. J. exp. Mar. Biol. Ecol. 17: 165-203

Parry, G. D. (1977). Life-history strategies of five species of intertidal limpets. Ph. D thesis, University of Melbourne

Parry, G. D. (1982). The evolution of the life histories of four species of intertidal limpets. Ecol. Monogr 52: 65-91

Quinn, G. P. (1985). The ecology of 2 populations of the intertidal pulmonate limpet, Siphonaria diemenensis Quoy and Gaimard, 1833. Ph. D. thesis, University of Melbourne
Quinn, G. P. (1988a). Ecology of the intertidal pulmonate limpet Siphonaria diemenensis Quoy et Gaimard. II. Reproductive patterns and energetics. J. exp. mar. Biol. Ecol. 117: 137-156

Quinn, G. P. (1988b). Ecology of the intertidal pulmonate Iimpet Siphonaria diemenensis Quoy et Gaimard. I. Population dynamics and availability of food. J exp. mar Biol. Ecol. 117: 115-136

Sokal, R. R., Rohif, F. J. (1981). Biometry. W. H. Freeman, San Francisco

Underwood, A. J. (1976). Analysis of patterns of dispersion of intertidal prosobranch gastropods in relation to macroalgae and rock pools. Oecologia (Berl.) 25: 145-154

Underwood, A. J. (1979). The ecology of intertidal gastropods. Adv. mar. Biol. 16: 111-210

Underwood, A. J. (1980). The effects of grazing by gastropods and physical factors on the upper limits of distribution of intertidal macroalgae. Oecologia (Berl.) 46: 201-213

Underwood, A. J., Denley, E. J., Moran, M. J. (1983). Experimental analyses of the structure and dynamics of midshore rocky intertidal communities in New South Wales. Oecologia (Berl.) 56: 202-219

Underwood, A. J., Denley, E. J. (1984). Paradigms, explanations and generalizations in models for the structure of intertidal communities on rocky shores. In: Strong, D. R., Simberloff, D., Abele, L. G., Thistle, A. B. (eds.) Ecological communities: conceptual issues and the evidence. Princeton University Press, Princeton, New Jersey, p. $151-180$

Winer, B. J. (1971). Statistical principles in experimental design. McGraw-Hill Kogakusha, Tokyo

This note was submitted to the editor; it was accepted for printing on August 3, 1988 